\title{
Vocational Quality Assurance Performance in Preparation for School Self-Evaluation in the Covid-19 Pandemic Era
}

\author{
Z. Arifin", S. F. A. Widodo, G. Wiyono, A. Sutikno, Darmono \\ Universitas Negeri Yogyakarta, Indonesia \\ *Corresponding author.Email:_zainal_arifin@uny.ac.id
}

\begin{abstract}
Many vocational high schools have implemented a school quality assurance system, but the quality of their graduates is still low. This study aimed to evaluate efforts made by school principals, teachers, school committees, and vocational students to achieve vocational quality assurance, especially in preparing the School Self Evaluation (SSE) as the main instrument in the accreditation activities of the school. The study was a descriptive quantitative research method. The samples were school principals, teachers, school committees, and vocational students in four vocational high schools implementing a Quality Assurance System, especially QMS ISO 9001:2008 or QMS ISO 9001:2015. The schools were located in Yogyakarta and Central Java. Research data were collected based on the results of the distribution of questionnaires (instruments), interviews, observations, documentation studies, and Focus Group Discussions (FGD). The data were analyzed based on the level of achievement of the eight National Education Standards (NES) that had been set in the syllabus. Several findings were obtained. First, schools used four stages: setting the standard, completing the standard, continuous evaluation, and quality improvement. Second, schools have taken correct and appropriate steps in achieving their vision and mission based on the formulated SPMI guidelines Third, schools have implemented eight NESs standards, including graduates, content, process, educational assessment, educators and education personnel, educational facilities and infrastructure, education management, and financing standards. Fourth, each vocational high school had similarities and differences in strategies and methods in achieving the school's vision and mission. This study has illustrated how the vocational high school conducts the quality assurance for school self-evaluation. Future studies should focus on providing more supports for these school to improve their quality.
\end{abstract}

Keywords: Covid-19 pandemic, quality assurance, vocational school

\section{INTRODUCTION}

The Covid-19 pandemic has caused the government to set various policies to maintain physical distance, stay away from activities in all forms of crowds, gatherings, and avoid gatherings that involve many people (including WFH for the education process in schools). Responding to such conditions, the role of the principal as a leader and manager in the school is becoming critical. The role of teachers, school committees, school supervisors, parents/guardians, and students is essential to achieving the school's vision and mission. Activity plans have been designed in the School Activity Plan
(SAP) and the School Activity Plan and Budget (SAPB), which of course, are affected by the Covid-19 pandemic.

This research is based on the main findings from the field observations in vocational high schools. First, the quality of vocational graduates is still low, especially with the current world problem, the Covid-19 pandemic. Second, there are still some quality standards of education that need to be improved and even increased their achievements. Third, many vocational high schools have implemented a school quality assurance system, but why is the quality of their graduates still low. 
The success of students is the success of their educational institutions [1]. Based on the basic understanding of quality mentioned above, it appears that quality is always focused on the customer (customer focus quality). Thus, products are designed, manufactured, and services are provided to meet customer desires.

ISO 8402 (Quality vocabulary) defines quality as the totality of the characteristics of a product that support its ability to satisfy specified or defined needs [2]. Quality is often defined as customer satisfaction or conformance to the needs or requirements. The product is the result of an activity or process. There are three product categories, that is (1) goods, such as cars, computers, motorcycles, houses, etc., (2) software, for example, computer programs, procedures, and others, (3) services, for example, banking, education, health, and others.

Quality assurance can be applied in education (schools), where schools seem to be a separate system of context, inputs, processes, outputs, outcomes (shortterm impacts and long-term impacts), where the focus of quality assurance is on located on the input [3]. The targets of quality assurance activities in the education sector are the stages: input, process, outcome, and impact. Targets in education include student selection and quality, curriculum, facilities and infrastructure, teachers and supporting staff, learning and assessment processes, graduate competencies, alumni and stakeholders, and academic management [4].

Quality assurance is an education quality management system. The main purpose of quality management is to prevent errors in the production process by ensuring that every step carried out during the production process is monitored from the beginning of the production process [5]. If an error occurs during the production process, repairs are immediately carried out so that a greater loss can be avoided. In the concept of quality management, the quality assurance system has an advantage, namely that the quality of the products produced will be guaranteed because the prevention of errors is closely monitored. The achievement to be obtained from quality management is to improve the quality of work, improve productivity, and increase efficiency through improving performance and improving work quality to produce products that satisfy or meet consumer needs standards [6]. Quality management is a set of procedures and processes to improve performance and improve the quality of work. The essence of quality management is a management system that continuously strives and is directed to increase customer satisfaction at a low cost. Cheap costs because the products produced are of high quality and free from failures that result in losses so that the ratio between output and input is very high [7].
In the context of education, quality management is a way of managing all educational resources directed so that all people involved in it carry out their duties with enthusiasm and participate in improving the implementation of work to produce services that match or exceed consumer needs [8]. So that in the context of education for the performance of the context of quality management with the concept and paradigm of quality assurance, various changes are needed, including philosophy, objectives, and ongoing processes [9].

There is some difference of opinion on the product of education. Learners, students, and alumni are often considered a product of education. But producing students with specific quality assurance standards is impossible. As Linton Gray put it that "humans are not equal, and they are in educational situations with experiences, emotions, and opinions that cannot be generalized" [10]. But one thing to remember is that student's success is the success of their educational institutions [1].

Based on the basic understanding of quality mentioned above, quality is always focused on the customer (customer focus quality). Thus, products are designed, manufactured, and services are provided to meet customer desires. To be able to meet the quality required quality management. ISO 8402 defines quality management as all activities of the overall management function that determine quality policies, objectives, and responsibilities and implement them through tools, such as (1) quality planning, i.e., the establishment and development of goals and requirements for quality and implementation of the quality system; (2) quality control, i.e., techniques and operational activities used to meet quality requirements; (3) quality assurance, i.e., all planned and systematic actions that are implemented and demonstrated to provide sufficient confidence that the product will satisfy the need for a certain quality; (4) quality improvement, i.e., actions taken to increase product value for customers through increasing the effectiveness and efficiency of processes and activities through the organizational structure [11]. Therefore, quality management is a capability inherent in human resources and is a controllable process and not a mere coincidence.

Therefore, this study examined school quality assurance in preparing SSE in the context of preparing and preparing for vocational high school accreditation. The target of quality assurance activities is a continuous cycle. The activity begins with the establishment of quality standards, followed by periodic monitoring and evaluation. The results of monitoring and evaluation will provide input for carrying out self-evaluation as feedback in setting standards for the next cycle. The essence of this activity is continuous quality improvement. 


\section{METHODOLOGY}

\subsection{Preparing the new file with the correct template}

This study used an evaluative research design with a quantitative-descriptive approach. This method was chosen to evaluate the performance of school quality assurance, especially in the preparation of SSE during the Covid-19 pandemic. The research population was all school residents who were the subjects of the study, consist of SMKN 2 Magelang, SMKN 2 Depok, SMKN 2 Yogyakarta, SMKN 2 Pengasih, and SMKN 2 Klaten.

Table 1. Number of Research Samples

\begin{tabular}{|l|c|c|c|c|c|}
\hline \multirow{2}{*}{ School } & \multicolumn{4}{|c|}{ Number of Research Samples (Person) } \\
\cline { 2 - 6 } & Principal & $\begin{array}{c}\text { Vice } \\
\text { Principal }\end{array}$ & Teacher & $\begin{array}{c}\text { School } \\
\text { Committee }\end{array}$ & Student \\
\hline $\begin{array}{l}\text { SMKN 2 } \\
\text { Yogyakarta }\end{array}$ & 1 & 3 & 30 & 2 & 36 \\
\hline $\begin{array}{l}\text { SMKN 2 } \\
\text { Pengasin }\end{array}$ & 1 & 3 & 30 & 2 & 36 \\
\hline $\begin{array}{l}\text { SMKN 2 } \\
\text { Depok }\end{array}$ & 1 & 3 & 30 & 2 & 36 \\
\hline $\begin{array}{l}\text { SMKN 2 } \\
\text { Klaten }\end{array}$ & 1 & 3 & 30 & 2 & 36 \\
\hline $\begin{array}{l}\text { SMKN 2 } \\
\text { Magelang }\end{array}$ & 1 & 3 & 30 & 2 & 36 \\
\hline Total & $\mathbf{5}$ & 15 & 150 & 10 & 180 \\
\hline
\end{tabular}

\section{RESULT AND DISCUSSION}

\subsection{Quality of SSE Content Standard}

The content standards used in this study consist of five sub-indicators, including curriculum development, curriculum structure, learning load, guidance and counseling services, and extra-curricular activities. In the range of the maximum score is 3 , then the overall score of the Content Standard is at a rating of 1.9 or in the percentage of $63.67 \%$ in a good category.

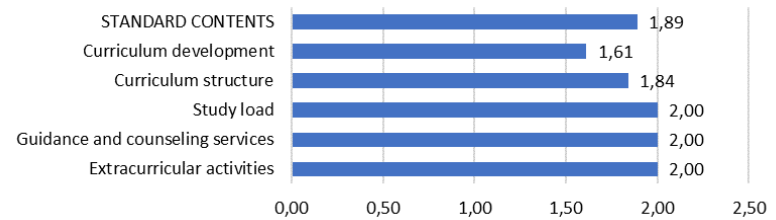

Figure 1 Quality of SSE Content Standard.

Figure 1 shows the lowest score is in curriculum development. Some factors for this low score is due to the suitability of teaching materials with the graduate competencies and the involvement of various parties in curriculum development. Besides, the less-than-optimal score of this content standard is due to the high comparison of teacher and student learning activities and the low percentage of local content subjects and self-development.

\subsection{Quality of SSE Process Standard}

The standard process that is used in this research consists of six sub-indicators, including syllabus quality, lesson plan quality, learning resources, classroom management quality, learning implementation, and also monitoring/ supervision and evaluation implementation. In the range of the maximum score is 3, the overall score of the Process Standard is at a rating of 1.48 or in the percentage of $49.33 \%$, which is categorized as in a sufficient category.

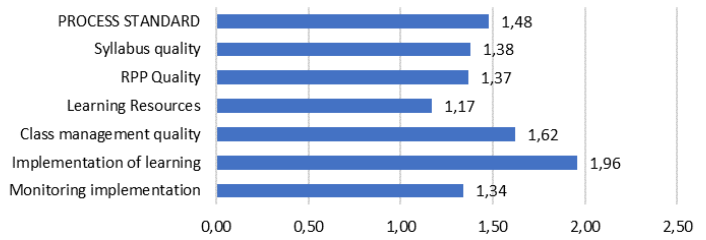

Figure 2 Quality of SSE Process Standard.

The data in Figure 2 shows that the lowest score is a learning resource. Some of the factors for this low score are due to the limited availability of books, guides, and learning resources owned by schools. Another factor is how the maximum utilization of these learning resources is used by teachers and students whose purpose is to provide independent study to students to explore learning assignments by optimizing learning resources owned by the school. This overall low average score is also influenced by the weak implementation of monitoring, supervision, and evaluation of learning. This cause is due to the low frequency in supervising principals in managing teacher learning in the classroom and the lack of follow-up steps for principals in guiding teachers in improving the findings found in learning supervision.

\subsection{Quality of SSE Graduate Competency Standard}

The Graduate Competency Standards that are used in this study consist of fifteen sub-indicators which are reflected in the graduates, including being confident and responsible, accustomed to using various learning resources, achievement, productive and responsible, habitual clean, healthy, fit, safe, and sportsmanship, ready to continue to a higher level of education, to communicate effectively and politely, to carry out religious teachings, to have a noble character, to enforce rules, to learn science and technology effectively, to recognize and analyse natural and social phenomena, and to express art and culture, physical fitness and healthy living, and also to maintain their body and environment. If the maximum score range is 3 , then the overall score of the Graduate Competency Standard is at a rating of 1.18 or in the percentage of $39.33 \%$ in the low category. 


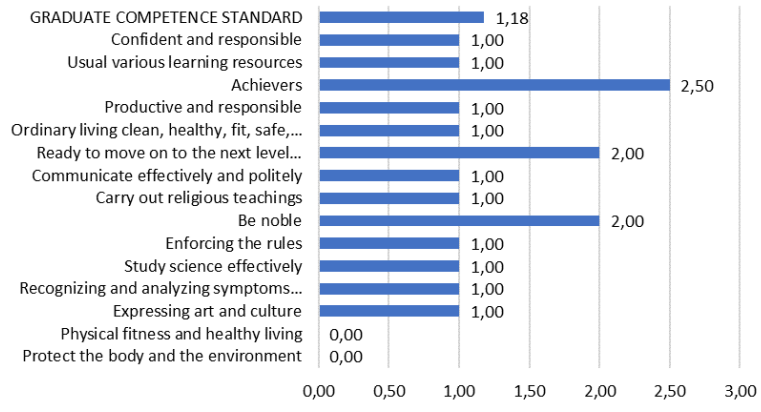

Figure 3 Quality of SSE Graduate Competency Standard.

The data in Figure 3 shows that the lowest score is reflected in students' self-efficacy, which is reflected in artistic and cultural expressions, ability to analyze symptoms, low levels of learning science and technology, inconsistency in law enforcement, lack of application of religious teachings, low effective but polite communication, low habits for health maintenance, lack of productivity and lack of sense of responsibility. The cause of the low competency standards of graduates is due to the limitations of school achievements and awards as well as the ability to get used to a healthy lifestyle both inside and outside, which will later reflect the graduate's self-character, which graduate users can confirm on the beliefs and responsibilities of graduates to be productive, analytical, and able to solve problems.

\subsection{Quality of SSE Educators and Staff Standard}

The Standards of Educators and Staff used in this study consist of fourteen sub-indicators covering. Teacher qualifications, teacher competencies, education staff qualifications, and education staff competencies. In the range of the maximum score is 3 , then the overall score of the Educators and Staff Standards is at a rating of 2.00 or in the percentage of $66.67 \%$ in a good category.

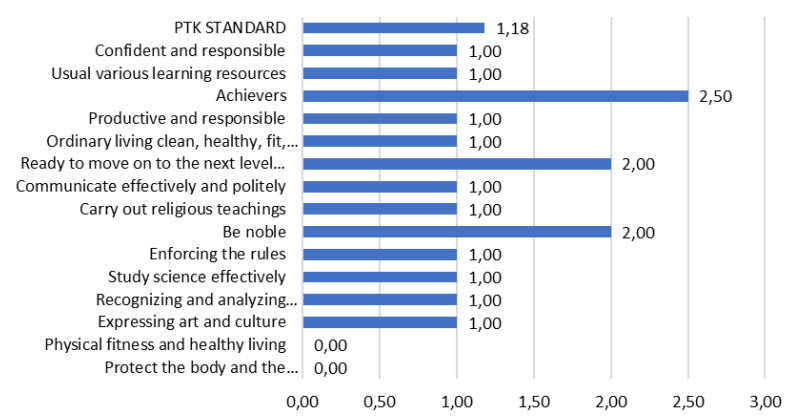

Figure 4 Quality of SSE Educators and Staff Standard.

The data in Figure 4 shows that the mean scores for all sub-indicators are the same. This indicates that the quality of Educators and Staff tends to show good results. This consistency is due to the appropriate
Educators and Staff qualifications, some teachers already have competency certificates, and the teacher's role in optimal learning.

\subsection{Quality of SSE Facilities and Infrastructure Standard}

The standard of facilities and infrastructure used in this study consists of sixteen sub-indicators which include the condition of the Education Unit, Land, Building, Classroom, Library, Science Laboratory, Leadership Room, Teacher's Room, Place of Worship, UKS Room, Latrine, Warehouse, Circulation room, Play/exercise area, Language Laboratory, and ICT Laboratory. In the range of the maximum score is 3, then the overall score of the Facilities and Infrastructure Standard is at a rating of 1.97 or in the percentage of $65.67 \%$ with a good category.

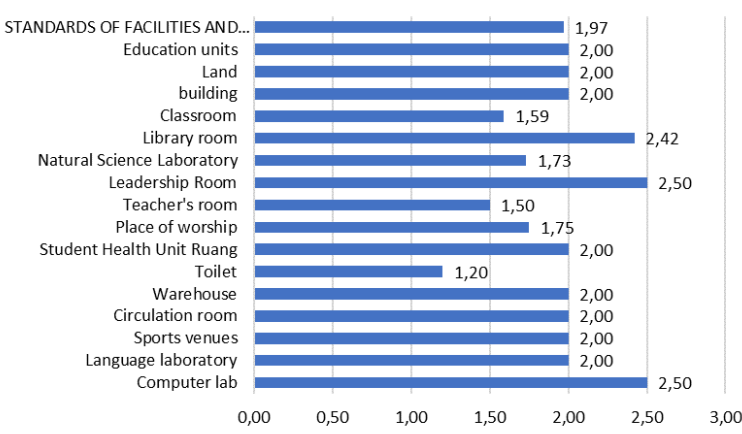

Figure 5 Quality of SSE Facilities and Infrastructure Standard.

The data in Figure 5 indicates that the lowest score is the quality of school latrines. This lowest score can be an input to schools that the smallest things such as latrines also need to be considered for quality and quantity. Based on the graph above, it has also been reflected that school facilities and infrastructure tend to show good grades. Awareness of improving facilities and infrastructure by schools and the culture that emerges from schools reflects progress in paying attention to the physical environment that is useful for supporting the learning process. In general, it is also seen that the quality of infrastructure in the leadership room and ICT laboratory has shown good quality.

\subsection{Quality of SSE Management Standard}

The Management Standards used in this study consist of fifteen sub-indicators which include: the scope and mechanism of establishing the school's vision, mission and goals, socializing the school's vision, mission, and goals, ownership of school work plans, school quality improvement programs, a realization of vision and mission into school work plans, schools prepare school management guidelines, schools create a conducive environment for learning activities, schools provide access to school financial management 
reports in a transparent and accountable manner, schools establish partnerships with other institutions, schools evaluate school work plans 2 times a year, the principal evaluates the utilization of educators, the school has carried out accreditation in accordance with applicable regulations, the participation of school residents, the principle applies effective leadership, and the school implements a management information system that is easily accessible by school residents. In the range of the maximum score is 3, then the overall score of the Management Standards is at a rating of 1.47 or in the percentage of $49.00 \%$ with a sufficient category.

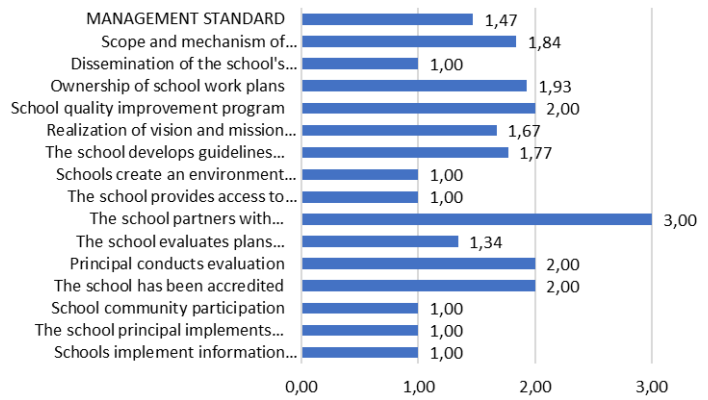

Figure 6 Quality of SSE Management Standard.

Based on the data in Figure 6. shows that the lowest score in school management in implementing information systems, lack of understanding in implementing effective leadership, low participation of school residents in school management, accountable and transparent reporting information for all parties, low in creating a conducive environment, and low vision socialization. And mission by the school so that the organization's basic values are less reflected in daily behavior. The low scores are because, in management, schools do not understand the management values shown in the quality of education. For example, the principal's leadership as the driving force of the school organization needs to function optimally through effective and efficient managerial functions. From the positive side of management standards, it was found that all schools in the respondents had collaborated with various relevant institutions even though the follow-up activities had not yet realized concrete and sustainable results.

\subsection{Quality of SSE Financing Standard}

The financing standards used in this study consist of six sub-indicators which include: RAPBS and RAKS compiled together with the School Commit-tee and taking into account the economic capabilities of students' parents, Standard Amount of Non-Personnel Operating Costs, Realization of Financing Amounts other than Non-Personnel Operations, ATS and BAHP, Realization Non-personnel Operations Financing Management, Non-Personnel Operations Financing Report Documents, and Non-Personnel Operations Financing Report Documents. If the maximum score range is 3, then the overall score of the Financing Standard is at a rating of 1.84 or in the percentage of $61.33 \%$ with a good category.

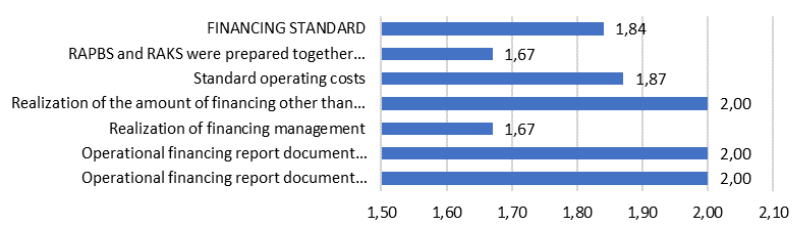

Figure 7 Quality of SSE Financing Standard.

Based on the data in Figure 7. shows that the lowest score is the realization of less-than-optimal financing management and the joint preparation of the RAPBS and RAKS. This is due to the minimal presence of the community in the practice of the RAPBS and RAKS. The transparency and credibility of the preparation of the development plan are some of the factors for the low score. In addition to that, the lack of accuracy in budget realization with activities due to incidental implementation so that some work programs may not run because of other programs that swell or there are many incidental programs outside the plan.

\subsection{Quality of SSE Assessment Standard}

The assessment standard used in this study consists of twelve sub-indicators which include: the assessment is valid, the assessment is carried out objectively, the assessment is carried out fairly, the assessment is carried out in an integrated manner, the assessment is carried out openly, the assessment is carried out comprehensively and continuously, the assessment is carried out in an integrated manner which include accountability, assessment techniques, mechanisms and procedures, assessment by educators, assessment by education units, and assessment by the government. In the range of the maximum score is 3 , then the overall score of the Assessment Standard is at a rating of 1.66 or in the percentage of $55.33 \%$ with a good category.

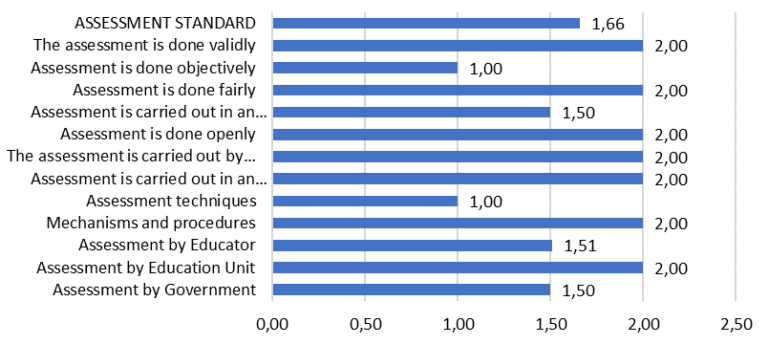

Figure 8 Quality of SSE Assessment Standard.

Based on the data in Figure 8. shows that the lowest score is the application of assessment techniques used by teachers is very limited and tends to be more cognitive measurement assessments. For measuring attitudes and skills, it is difficult for teachers to apply. In addition, the objectivity of the assessment also affects the validity and credibility of the teacher. Even though the lesson plans have been stated in the RPS, difficulties 
in implementing the assessment have hindered teachers in carrying out learning assessments. Broadly speaking, the teacher has made a valid, accountable, and procedural assessment.

\subsection{Discussion}

The quality of education is influenced by 8 Education Quality Standards which include: Content Standards, Process Standards, Graduate Competency Standards, Educators and Staff Standards, Facilities and Infrastructure Standards, Management Standards, Financing Standards, and Assessment Standards. Percentage Figure 9 shows a clear difference, especially in quality output, namely the low Graduate Competency Standards $(39.33 \%)$ with other standards. With this unsatisfactory output, the reflection of graduates' competence in the presence of the Covid-19 pandemic will result in low-quality graduates.

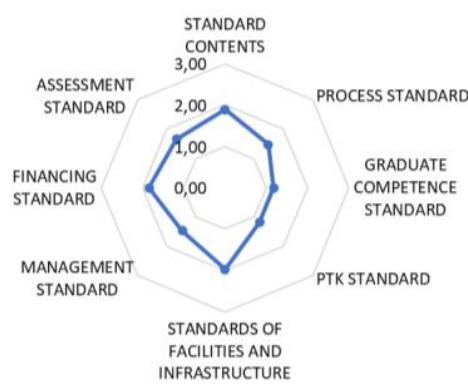

Figure 9 Education Quality Net.

Figure 9 shows that the critical value is in the Graduate Competency Standards. The existence of online learning reduces the quality and quantity of teaching. This impacts filling the SSE, which is less than optimal because all face-to-face learning activities become non-variant, especially in the implementation and management of learning. Supervision of school principals with limited online supervision is also the cause of how the SSE becomes less than optimal and tends to be difficult to increase scores in graduate quality assessments.

\section{CONCLUSION}

The conclusions of the research are as follows: (1) Stakeholder assessment of school quality assurance performance in the preparation of EDS during the Covid-19 pandemic resulted in an average score of 1.69 with the percentage of achievement being 56.29. (2) The lowest score in filling out the EDS is the Graduate Competency Standard with a score of 1.18 or in the percentage of $39.33 \%$ and is included in the low category.

\section{AUTHORS' CONTRIBUTIONS}

ZA, GW and D conceived of the idea. ZA and GW developed the theory and performed the computations. S and D verified the analytical methods. ZA and $\mathrm{W}$ conduct data analysis result and supervised the findings of this work. All authors discussed the results and contributed to the final manuscript.

\section{ACKNOWLEDGMENTS}

We thanks to Postgraduate Program Yogyakarta State University, who has funding in the subject research and has been a potential source of constant encouragement, extensive consultancy, and feasible solutions to all of the challenges and constraints during one semester of our research in the major of Educational Management.

\section{REFERENCES}

[1] Sallis, E. Total Quality Management in Education. Alih Bahasa: Ahmad Ali Riyadi \& Fahrurrozi. Cetakan VIII. Penerbit IRCiSoD, 2008.

[2] Khoiri, M. Makalah Seminar Nasional VI SDM Teknologi Nuklir Yogyakarta, 18 November 2010 ISSN 1978-0176. STTNBATAN \& Fak. Saintek UIN Sunan Kalidjaga, 2010.

[3] Slamet, P. H. Hand Out Learning of Quality Assurance in Education at Post Graduate Program Study Program Education Supervision Management in MM UGM Yogyakarta $2^{\text {nd }}$ batch, 2012.

[4] Schleicher, A. Preparing teacher and developing school leaders for the 21 st century lessons from around the world. OECD Publishing, 2012.

[5] Bush, T. Leadership and management development in education. Sage Publication, Ltd, 2010.

[6] Cunningham, W.G., \& Cordeiro, P.A. Educational leadership a bridge to improved practice. Pearson, 2009.

[7] Hallinger, P. 2003. Leading Educational Change: Reflections on the practice of instructional and transformational leadership, Cambridge Journal of Education 33 (3): 35-70.

[8] Hoy. W.K., \& Miskel, C.G. Educational administration: theory, practice, and research. 9th Edition. McGraw-Hill, 2013.

[9] Huber, G. S. School Leadership International Perspective. Springer, 2010.

[10] Levin, B. How to change 5000 schools a practical and positive approach for Leading change at every level. Third Printing. Cambridge, Harvard University Press, 2012.

[11] McMillan, J.H. Educational research fundamentals for the consumer. Sixth Edition. Pearson, 2013. 